\title{
Does the late Pliocene change in the architecture of the Antarctic margin correspond to the transition to the modern Antarctic Ice Sheet?
}

\author{
M. Rebesco ${ }^{1}$ and A. Camerlenghi ${ }^{2}$ \\ ${ }^{1}$ Istituto Nazionale di Oceanografia e di Geofisica Sperimentale, Borgo Grotta Gigante 42/C, 34010 Sgonico (TS) Italy (mrebesco@ogs.trieste.it) \\ ${ }^{2}$ ICREA and Depart. d'Estratigrafia, P. i Geociencies Marines, Universitat de Barcelona, C/ Martí i Franques, s/n, E-08028 Barcelona, Spain \\ (acamerlenghi@ub.edu)
}

\begin{abstract}
We observe in 6 key sectors of East and West Antarctica continental margin a change in the geometry of the sedimentary deposits which is characterized by: margin-wide erosion and subsequent progradation on the continental shelf; downlap on the continental slope; major mass wasting deposits on the continental rise. The change occurs in the late Neogene in all sectors, though some natural variation exists, and the stratigraphic position is not obvious for every margin. The change is apparently synchronous and dated about $3 \mathrm{Ma}$ in Antarctic Peninsula and Prydz Bay margins and broadly concomitant in the others sectors. This suggests a common driving force, which we suggest to be the transition of the Antarctic ice sheet regime from polythermal to present polar cold, dry-based conditions.
\end{abstract}

Citation: Rebesco, M. and A. Camerlenghi (2007), Does the Late Pliocene change in the architecture of the Antarctic margin correspond to the transition to the modern Antarctic Ice Sheet?, in Antarctica: A Keystone in a Changing World - Online Proceedings of the $10^{\text {th }}$ ISAES X, edited by A. K. Cooper and C. R. Raymond et al., USGS Open-File Report 2007-1047, Short Research Paper 021, 4 p.; doi:10.3133/of2007-1047.srp021.

\section{Introduction}

The Antarctic Ice Sheet (AIS) switched from an earlier warm, highly dynamic regime to the modern cold, stable one sometime during the Neogene period. Timing and circumstances of this switch have been controversial for over 20 years, with two main inferences: 1) permanently cold stable ice sheet since the middle Miocene (e.g. Denton et al., 1993); 2) predominantly cold polar and stable later than the Middle Miocene (e.g. Late Miocene, Hambrey and McKelvey, 2000). Periods of increased dynamism in the Pliocene, (e.g. Webb et al., 1984) and in the late Pleistocene (Scherer et al., 2000) are also reported.

Evidence for a late Pliocene polythermal to polar evolution of the Antarctic continental margin has been presented recently by Rebesco et al., (2006), Diviacco et al., (2006) Volpi et al., (2007) and Donda et al. (2007), and Rebesco and Camerlenghi (2007). Such evidence suggests that the high sediment input from focused ice streams produces a phase of margin instability during the transition to polar conditions, characterized by enhanced margin progradation.

The aim of this paper is to synthesize a model to explain the late Pliocene change in the architecture of the Antarctic margin as a response to the transition to the modern, polar, cold-based Antarctic Ice Sheet.

\section{Seismic characteristics of the late Pliocene change}

In the key sectors of East and West Antarctica continental margin analyzed by Rebesco et al (2006), Rebesco and Camerlenghi (2007), and by this study (Antarctic Peninsula, Prydz Bay, Weddell Sea, Wilkes Land, East and West Ross Sea, figure 1) we observe a change in the geometry of the late Neogene sedimentary deposits that is characterized by:

1) Margin-wide erosion and subsequent progradation on the continental shelf
The change is from widespread margin progradation across the whole continental shelf to focused progradation within major glacial troughs and aggradation on adjacent continental shelf banks. The troughs are tectonically controlled (like e.g. that in the Lambert Graben inshore of Prydz Bay) in most if not all cases. The erosional unconformities marking the initiation of new troughs or the deepening of pre-existing troughs is closely associated to a continental scale erosional episode linked to enhanced glacial erosion.

\section{2) Downlap on the continental slope}

Downlapping surfaces are especially evident towards the base of the continental slope, where they are located at shallow sub-bottom depth and they define the toe of the last major glacial shelf/slope prograding wedge. As a consequence of the faster progradation of the shelf edge with respect to lower slope, the margin became increasingly steeper (slope angle often in excess of 10-15 degrees) and the upper continental slope became the sedimentary depocenter of the glacial marine sedimentary sequence. Previously, the depocenters were located on the continental rise.

\section{3) Major mass wasting deposits on the continental rise}

Large mass wasting deposits, including mega debris flows, are common features in the continental rise of northern high-latitude margins (e.g. Evans et al., 2005). In Antarctic margins only few examples of these features are know: In the Pacific Margin of the Antarctic Peninsula, the Alexander channel mega debris-flow deposit between sediment drift 7 and 6 (Diviacco et al., 2006) and another large debris-flow deposit within sediment drift 4 (Volpi et al., 2005) have been ascribed to the Late Pliocene, while a smaller debris-flow deposit SW of sediment drift 5 has been ascribed to the early Pliocene (Hernandez-Molina et al., 2006). On the lower slope and rise of the Western Wilkes Land margin, a variety of Neogene sediment mass 


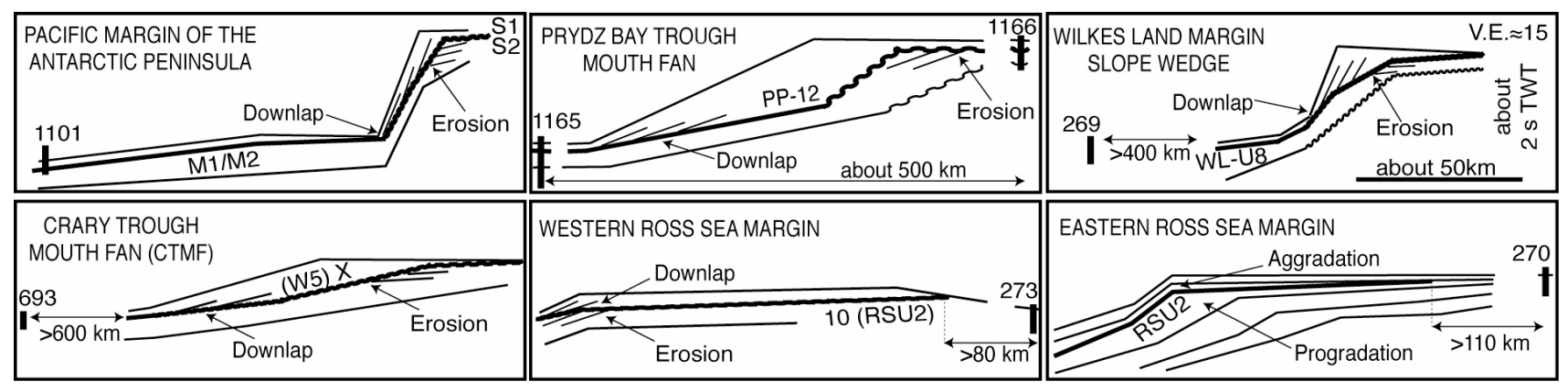

Figure 1. Simplified models of continental margin development illustrated by stratal geometries in six key sectors of the East and West Antarctic continental margin (from Rebesco et al., 2006): Antarctic Peninsula margin (from profile 114 of Rebesco et al., 2006); Prydz Bay Trough (from the composite profile of Cooper and O'Brien, 2004); Crary Trough Mouth Fan (from profiles AWI 90190 and 90-110 of Oszkò, 1997); Wilkes Land margin (from profile WEGA35 of De Santis et al., 2003); Western Ross Sea margin (from profile 37 of Bart et al., 2000) and Eastern Ross Sea margin (from profile BGR 7 of De Santis et al., 1995).

movement deposits (including mega debris flow deposits) have been mostly ascribed to the Miocene (Donda et al., 2007). In the Weddell Sea, the collapse of the Crary Trough Mouth Fan indicated by mass wasting of the slopes has been ascribed to the early Pliocene (Bart et al., 1999).

The general characters of the change in the sedimentary architecture of the continental shelf are shared by all key sectors of East and West Antarctica continental margin, though some natural variation exists in any specific case. The change occurs in the late Neogene, though the stratigraphic position is not obvious for every margin. The Cenozoic sedimentary successions of the Antarctic continental shelves are very discontinuous due to the erosion by grounded ice, and often hardly datable. Conversely, the sedimentary successions of the Antarctic continental rises contain a continuous and relatively expanded, datable, indirect record of the ice sheet behaviour. The direct correlation through high quality seismic data between continental shelf and rise stratigraphy helped in the reconstruction of the timing and circumstances of ice sheet evolution (Rebesco et al., 2006; Bart et al., 2005). This change is hence well constrained in some regions (e.g. the Antarctic Peninsula Pacific margin, where continental shelf erosion can be correlated to the borehole stratigraphy of the hemipelagites on the continental rise) and less well constrained in others (e.g. the Prydz Bay margin where the only borehole stratigraphic record on the continental rise is not tied directly to the seismic stratigraphy of the continental shelf by high resolution seismic data). The change occurs in the late Neogene, though the stratigraphic position is not obvious for every margin. The age of the change is estimated at $2.9 \pm 0.2$ Ma by Rebesco et al. (2006) and Rebesco and Camerlenghi (2007) in the Pacific Margin of the Antarctic Peninsula, and between 4.1 and $2.5 \mathrm{Ma}$ in the Prydz Bay margin by Volpi et al. (2007).
New insights are promised by the recently drilled (with over 98\% recovery) ANDRILL cores from the Ross Ice Shelf. These show strongly cyclic mid-late Pliocene alternations between diamictite and diatomite above a thick Early-Middle Pliocene interval of diatomite representing an extended period of ice-free conditions (Naish et al., 2007).

\section{Evolutionary model}

The synchronous (between Antarctic Peninsula and Prydz Bay) and broadly concomitant (Wilkes Land, Wedded Sea, and Ross Sea) late Neogene continental shelf erosion, continental slope progradation, and shift of the sedimentary depocenters from the continental rise to the slope, with subsequent sediment starvation on the continental rise, suggest a common driving force, which we suggest to be the transition of the Antarctic ice sheet regime from polythermal to polar cold, dry-based conditions like at present.

The AIS, and especially its eastern portion, is presently characterized by a cold, dry-based regime outside the major ice streams located at the convergence of glacial drainage. Melting of the ice sheet is insignificant in the present polar setting. The rate of ice movement under polar conditions in comparison to that under temperate ice masses is magnitudes less (Menzies, 1996). The main process responsible of the progradation of the continental margin is thought to be the rapid debris flow accumulation on the slope during long lasting cold glacial periods, when the ice sheet was grounded at or near the continental shelf edge. It is intuitive that during the cold glacial stages of the polar regime, basal meltwater was much less than at present. If present, it did not exist in extensive enough layers to allow a substantial flow of the ice sheet by basal sliding and/or basal sediment deformation.

During the early stages of development of the Antarctic ice sheet, when the global climate was warmer, ice sheet conditions were characterized by a relatively 
warm (with temperature and pressure allowing ice melting) and wet ice base. In that regime the water was relatively abundant and may have fed a well developed subglacial drainage net, which favored an accentuated dynamism of the ice sheet, with rapid fluctuation of expansion and volume.

Between these two end-member regimes are intermediate polythermal ice sheet regimes, characterized by alternations in time and space of wet-based and frozenbed conditions. In Antarctica polythermal ice sheet conditions are suggested by glacio-marine sediments like the Pagodroma Group, whose age (generally assumed Oligocene to Plio-Pleistocene, Hambrey and McKelvey, 2000) has been debated for over 20 years.

We infer that such kind of polythermal glaciers operated the offshore transport of sediments along the Antarctic continental margin till the $3 \mathrm{Ma}$ change that we identify in the seismic stratigraphy. When grounded to the shelf edge, polythermal glaciers delivered sediments to the upper slope in the form of gravity flows (debris and turbidity flows), evidently inducing an appreciable seaward progradation of the margin. It is likely that dynamic and efficient means of transport of sediment were very widely distributed on the Antarctic shelves and relatively free to migrate laterally (though subject to morphologic constrains). We infer that the widespread spatial and temporal distribution of point sources at the shelf edge resulted in a relatively even progradation of the continental slope (Fig. 2). Melt water at the mouth of the glaciers grounded at the shelf-edge favored the sediment transport toward the continental rise. Sediment reworking by subglacial meltwater generates relatively well sorted deposits with relatively lower shear strength. The mass wasting of such deposits will generate preferentially lowdensity debris flows with a relatively long run-out distance and hyperpycnal/turbidity flows at the mouth of the glaciers. As a consequence of this efficient sediment delivery to the deep-sea, large, sometimes huge channel levee systems (e.g. Weddell Sea and Wilkes Land margins) and sediment drifts (e.g. Antarctic Peninsula and Prydz Bay margins) are found on the Antarctic continental rises.

As a consequence of the onset of the last global cooling trend in the late Pliocene (approximately $3 \mathrm{Ma}$, Zachos et al., 2001), meltwater persisted only at the base of a few large ice streams (such as those flowing in the Crary and Prydz troughs). With respect to the adjacent banks, subglacial meltwater within troughs is favored by the convergence of the ice flow lines and by the increased thickness and speed of the ice, which increase the basal pressure and frictional heat, that in turn lead to melting conditions. As a result, large amounts of sediment were transported to the shelf edge in the mobile basal layer of the ice streams flowing in the troughs, while a much lower amount of sediment was deposited by slowermoving ice on the adjacent banks.

Focused sediment load and faster progradation of sedimentary wedges induced episodes of early failure of the continental slope which included major mass wasting and "margin collapse". The mass wasting episodes on the Antarctic margin are responsible for the outermost part of the regional erosional surfaces that mark the onset of the rapid progradation of the shelf edge, stratal downlap and continental slope steepening. Further inland on the continental shelf, such erosional surfaces resulted from the development of polar thermal conditions were overdeepened in correspondence of the inner shelf glacial troughs. Such surfaces are those identified with different names in most sectors of the Antarctic margins (S1, PP12, W5, WL-U7, RSU2). The continental rise debris flow deposits are therefore the distal sedimentary expression of the erosion having taken place in the upper slope and on the continental shelf at the mouth of the major ice streams.

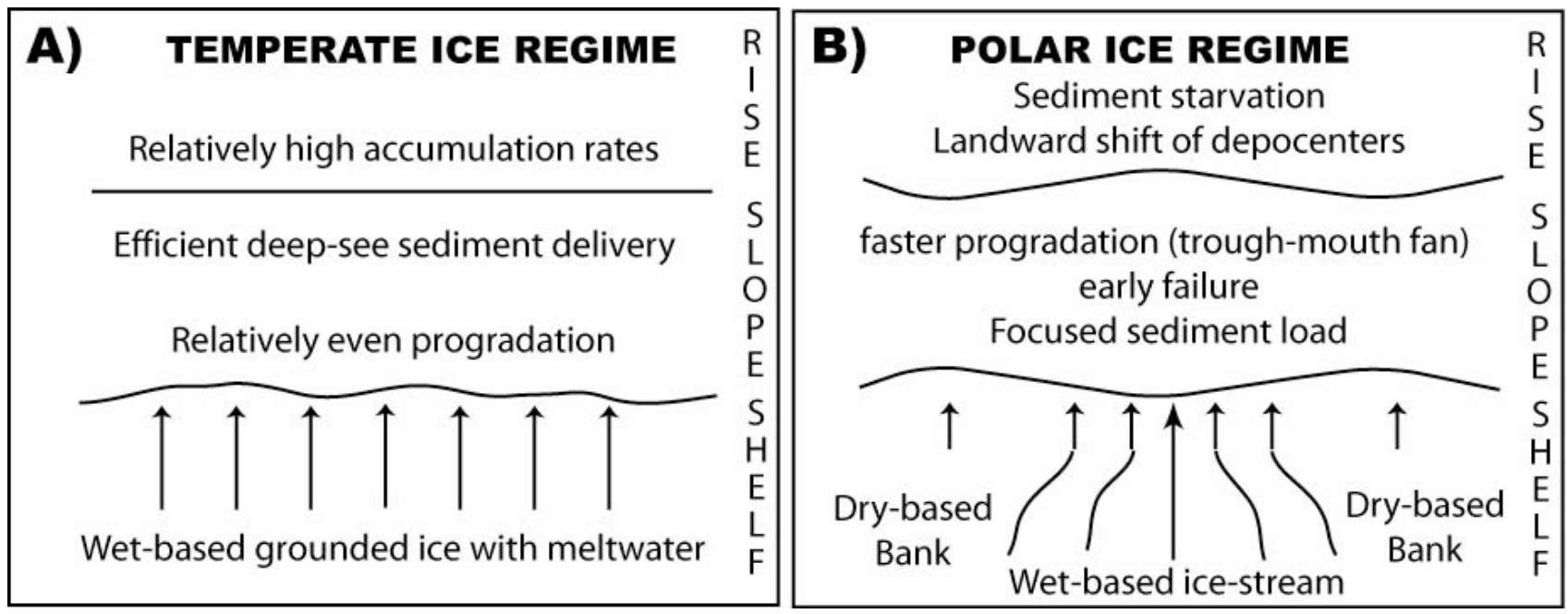

Figure 2. Schematic diagram showing the inferred pattern of the depositional system in Antarctica. A) during polythermal conditions at the base of the ice sheet; B) during present polar conditions margin (from Rebesco and Camerlenghi, 2007). 
The seismic record shows that after $3 \mathrm{Ma}$, during the cold dry-based ice sheet regime, the margin prograded without further major collapses, and became gradually stable. We infer that this stability derive from the increased shear strength of the coarser, less sorted sediments, combined to the static equilibrium reached by underlying sediments.

Late Pliocene- Pleistocene deposition concentrated on the continental slope at the mouth of the large troughs, generating large fans (e.g. Crary and Prydz trough mouth fans). The depocenters shifted from the continental rise toward the upper part of the continental slope. The continental rise was progressively deprived of sediments.

\section{Conclusions}

A change in the geometry of the sedimentary deposits in 6 key sectors of East and West Antarctica continental margin has been observed and interpreted to have been produced by the changes in sedimentary regime that followed the transition of the Antarctic ice sheet thermal regime from polythermal to the present polar cold, drybased conditions. The architectural change and hence the thermal regime change is dated to about $2.95 \mathrm{Ma}$ (with an uncertainty of at least 0.2-0.3) in the Antarctic Peninsula Pacific margin. It may be broadly concomitant in the other sectors considered.

A model is put forward, which implies that after the late Pliocene meltwater persisted only at the base of a few large ice streams. Subsequent focused sediment load induced major failure episodes of the continental slope, faster progradation of sedimentary wedges, stratal downlap, continental slope steepening and continental rise starvation.

Acknowledgements. Tim Naish and Eugene Domack are acknowledged for their constructive review and Howard Stagg is thanked for his editorial handling.

\section{References}

Bart, P. J., J. B. Anderson, F. Trincardi, and S. S. Shipp (2000), Seismic data from the Northern basin, Ross Sea, record extreme expansions of the East Antarctic Ice Sheet during the late Neogene, Marine Geology, $166,31-50$

Bart, P. J., M. DeBatist, and W. Jokat (1999), Interglacial collapse off Crary Trough Mouth Fan, Weddell Sea, Antarctica: implications for Antarctic Glacial History, Journal of Sedimentary Research, 69, 12761289.

Bart, P. J., D. Egan, and S. A. Waarny (2005), Direct constraints on Antarctic Peninsula ice sheet grounding events between 5.12 and 7.94 Ma., J. Geophys. Res., 110 F04008, doi 10.1029/2004JF000254

Cooper, A. K., and P.E. O'Brien (2004), Leg 188 synthesis: transitions in the glacial history of the Prydz Bay region, East Antarctica, from ODP drilling, in Proceedings of the Ocean Drilling Program, Scientific results, Volume 188, by A. K. Cooper, P. E. O'Brien, et al., College Station, Texas, Ocean Drilling Program: http://wwwodp.tamu.edu/publications/188_SR/synth/synth.htm

De Santis, L., G. Brancolini and F. Donda (2003), Seismo-stratigraphic analysis of the Wilkes Land continental margin (East Antarctica): influence of glacially driven processes on the Cenozoic deposition, Deep Sea Research Part II, 50, 1563-1594.

De Santis, L., J. B. Anderson, G. Brancolini, and I. Zayatz (1995), Seismic record of Late Oligocene through Miocene glaciation on the central and eastern continental shelf of the Ross Sea, in Geology and
Seismic Stratigraphy of the Antarctic Margin, edited by A. K. Cooper, P. F. Barker, and G. Brancolini, pp 235-260, American Geophysical Union Antarctic Researches Series, 68.

Denton, G. H., D. E. Sugden, D. R. Marchant, B. L. Hall, and T.I. Wilch (1993), East Antarctic ice sheet sensitivity to Pliocene climate change from a Dry Valleys perspective, Geograf. Ann., 75A, 155-204.

Diviacco, P., M. Rebesco, and A. Camerlenghi (2006), Late Pliocene mega debris flow deposit and related fluid escapes identified on the Antarctic continental margin by seismic reflection data analysis, Marine Geophysical Researches, 27, 109-128.

Donda, F., P. E. O'Brien, L. De Santis, G. Brancolini, and M. Rebesco (2007), Mass wasting processes in the Western Wilkes Land margin: implications Antarctic glacial history, Paleo3, in press.

Evans, D., Z. Harrison, P. M. Shannon, J. S. Laberg, T. Nielsen, S. Ayers, R. Holmes, R. J. Hoult, B. Lindberg, H. Haflidason, D. Long, A. Kuijpers, E. S. Andersen, and P. Bryn (2005), Paleoslides and other mass failures of Pliocene to Pleistocene age along the glaciated European margin, Marine and Petroleum Geology, 22, 1131-1148.

Hambrey, M. J., and B. C. McKelvey (2000), Neogene fluctuations of the East Antarctic Ice Sheet: Stratigraphic evidence from the Lambert Glacier region, Geology, 28, 887-890.

Hernandez-Molina, F.J., R. D. Larter, A. Maldonado, and J. RodriguezFernandez (2006), Evolution of the Antarctic Peninsula Pacific Margin Offshore from Adelaide Island Since the Late Miocene: An Example of a Glacial Passive Margin, in Workshop on Frontiers and Opportunities in Antarctic Geosciences edited by C. Siddoway, and C. A. Ricci, pp 81-90, Terra Antartica Reports, 12.

Menzies, J. (Ed) (1996), Past glacial environments, Volume 2, Butterworth-Heinemann.

Naish, T., R. Powell, and ANDRILL MIS Project Science Team (2007), A new high-resolution, glacimarine stratigraphic record of Antarctic glacial and climate history for the last 10 million years: (1) A preliminary stratigraphic framework and cyclostratigraphy for the ANDRILL McMurdo Ice Shelf Project drill core, Geophysical Research Abstracts, 9, 10338.

Oszkó, L. (1997), Tectonic structures and glaciomarine sedimentation in the south-eastern Weddell Sea from seismic reflection data, Berichte zur Polarforschung. 222, 153 pp.

Rebesco, M., and A. Camerlenghi (2007), Late Pliocene margin development and mega debris flow deposits on the Antarctic continental margins: evidence of the onset of the modern Antarctic Ice Sheet?, Paleo3, in press.

Rebesco, M., A. Camerlenghi, R. Geletti, and M. Canals (2006), Margin architecture reveals the transition to the modern Antarctic Ice Sheet (AIS) at about $3 \mathrm{Ma}$, Geology, 34, 301-304.

Scherer, R.P., A. A. Aldahan, S. Tulaczyk, G. Possnert, H. Engelhardt, and B. Kamb (2000), Pleistocene collapse of the West Antarctic ice sheet: Science, 281, 82-85.

Volpi, V., M. Rebesco, and P. Diviacco (2007), New insights in the evolution of antarctic glaciation from depth conversion of well-log calibrated seismic section of Prydz Bay, International Journal of Earth Sciences, in press.

Volpi, V., et al. (2005), Recent to Late Neogene seafloor instabilities on the deep Pacific margin of the Antarctic Peninsula, , NGF Abstracts and Proceedings of the Geological Society of Norway (2nd. International Conference on Submarine Mass Movements and Their Consequences), 2, 94-95

Webb, P. N., D. M. Harwood, B. C. McKelvey, J. H. Mercer, and L. D. Stott (1984), Cenozoic marine sedimentation and ice-volume variation on the East Antarctic Craton, Geology, 12, 287-291

Zachos, J. C., M. Pagani, L. Sloan, E. Thomas, and K. Billups (2001), Trends, rhythms and aberrations in global climate 65 Ma to present, Science, 292, 686- 693. 